\title{
WIDYA BIOLOI \\ E ISSN : \\ KONTAMINASI SOIL TRANSMITTED HELMITHS PADA HELAIAN DAUN \\ DAN CARA PENCUCIAN SAYURAN KUBIS DI PASAR TRADISIONAL KABUPATEN TABANAN
}

\section{(SOIL TRANSMITTED HELMITHS CONTAMINATION IN LEAVES AND HOW TO WASH THE CABBAGES IN THE TABANAN TRADITIONAL MARKET)}

\author{
Tri-Widianingsih, N.K., ${ }^{1}$ Yuliana, E. D., ${ }^{1}$ Suardana, A.A.K. ${ }^{1}$ \\ ${ }^{1}$ Program Studi Biologi, Fakultas. MIPA, Universitas Hindu Indonesia Denpasar, Bali, \\ Indonesia \\ Email :
}

\begin{abstract}
This study aimed to determine the types of STH that contaminate cabbages in the Tabnan traditional market, and to determine the effect of leaf position and washing method on STH contamination. This study using completely randomized experimental design. The research was carried out in the Tabanan traditional market. A total of 28 cabbage were taken in 10 traditional markets in Tabanan Regency. Laboratory tests were conducted to determine the presence of STH were carried out by $0.2 \% \mathrm{NaOH}$ sedimentation technique and centrifugation. The STH examination method uses the Kato-Katz method. The results of the study found soil transmitted helminth larvae on the strands of the outer cabbage leaves without washing and stagnant water washing. STH larvae found were filariform larvae of Necator americanus and Ancylostoma duodenale on the outer strands without washing. Whereas in the outermost strands with stagnant water washing only filariform larvae of Necator americanus were found. When compared to the average number of three replications, in the outermost cabbage strands without washing found more larvae compared to stagnant water washing. In the outermost strands by washing the running water there was no STH contamination nor did the middle strands and inner strands, either without washing, washing in stagnant water or washing water flow. However before consumption, cabbage should be washed with running water, to avoid infection with STH through the oral route.
\end{abstract}

Keywords: cabbage strands, contamination, Soil Transmitted Helminth

\begin{abstract}
ABSTRAK
Penelitian ini bertujuan untuk mengetahui jenis-jenis STH yang mengkontaminasi sayuran kubis di pasar tradisonal Kabupaten Tabanan, dan untuk mengetahui pengaruh posisi helaian daun dan cara pencucian daun kubis terhadaap kontaminasi STH. Rancangan penelitian ini menggunakan rancangan dasar adalah rancangan acak lengkap, sedangkan rancangan perlakuannya adalah rancangan faktorial. Penelitian dilaksanakan di pasar tradisional Kabupaten Tabanan. Sampel berjumlah 28 kubis yang diambil di 10 pasar tradisonal yang ada di Kabupaten Tabanan. Pemeriksaan laboratorium untuk mengetahui keberadaan STH yang dilakukan dengan teknik
\end{abstract}


WIDYA BIOLOI

E ISSN :

sedimentasi $\mathrm{NaOH}$ 0,2\% dan sentrifugasi. Metode pemeriksaan STH menggunakan metode Kato-Katz.Hasil penelitian ditemukan larva soil transmitted helminth pada posisi helaian daun kubis terluar tanpa pencucian dan pencucian air tergenang. Jenis larva STH yang ditemukan adalah larvafilariformNecator americanus dan Ancylostoma duodenale pada helaian terluar tanpa pencucian. Sedangkan pada helaian terluar dengan pencucian air tergenang hanya ditemukan larva filariformNecator americanus. Jika dibandingkan rata-rata jumlah tiga ulangan, pada helaian kubis terluar tanpa pencucian ditemukan lebih banyak larva dibandingkan dengan pencucian air tergenang. Pada helaian terluar dengan pencucian air mengalir tidak ditemukan adanya kontaminasi STH begitu pula pada helaian tengah dan helaian dalam, baik tanpa pencucian, pencucian pada air tergenang maupun pada pencucian air mengalir. Walaupun demikian, sebelum dikonsumsi sayuran kubis sebaiknya dicuci dengan air mengalir, untuk menghindari terinfeksi STH melalui jalur oral.

Kata kunci : helaian kubis, kontaminasi, Soil Transmitted Helminth

\section{PENDAHULUAN}

$\begin{array}{rrr}\text { Kecacingan } & \text { adalah masalah } \\ \text { kesehatan yang masih banyak }\end{array}$
ditemukan. Berdasarkan data dari World Health Organization (WHO) lebih dari 1,5 miliar orang atau $24 \%$ dari populasi dunia terinfeksi Soil Transmitted Helminths (STH). Infeksi tersebar luas di daerah tropis dan subtropis dengan jumlah terbesar terjadi di sub-Sahara Afrika, Amerika, Cina dan Asia Timur (WHO, 2013).

$$
\text { Infeksi cacing merupakan }
$$
permasalahan yang banyak ditemukan di negara berkembang salah satunya di Indonesia. Di Indonesia angka kesakitan karena terinfeksi cacing usus atau perut cukup tinggi. Hal ini dikarenakan letak geografis Indonesia di daerah „upik yang mempunyai iklim yang panas akan tetapi lembab. Pada lingkungan yang memungkinkan, cacing usus dapat berkembang biak dengan baik terutama oleh cacing yang ditularkan melalui tanah (Soil Transmitted Helminth). Penularan cacing usus bisa terjadi melalui makanan atau minuman yang tercemar, melalui udara yang tercemar atau secara langsung melalui tangan yang tercemar telur cacing yang infektif (Astuti dan Siti, 2008).

Di Bali berdasarkan hasil penelitian yang dilakukan Kapti et al. (2008), diperoleh prevalensi infeksi cacing usus pada anak SD di daerah Bali selama kurun waktu 2003-2007 tergolong tinggi yaitu berkisar antara 40,94\%- 92,4\%. Penelitian lain yang dilakukan di SD N 1 Luwus, Kecamatan Baturiti, Kabupaten Tabanan, dari 


\section{WIDYA BIOLOI}

E ISSN :

pemeriksaan tinja yang dilakukan terhadap 140 orang siswa/i, ditemukan sebanyak 54 orang atau sebesar $38,57 \%$ yang terinfeksi cacing (Damayanti, 2012).

Cara penularan telur cacing STH ke manusia menurut WHO (2013), melalui 3 jalur, antara lain (1) memakan sayuran yang kurang matang, kurang bersih dicuci/dikupas, tidak dicuci, serta mengandung telur cacing, (2) meminum air yang terkontaminasi telur cacing, dan (3) telur yang tertelan oleh anak-anak yang selesai bermain di tanah yang terkontaminasi dan kemudian meletakkan tangan mereka di mulut atau makan tanpa mencuci tangan. Jalur penularan cacing melalui memakan sayuran mudah terjadi dalam kehidupan sehari-hari sebab sayur adalah makanan yang sangat diperlukan oleh tubuh.

Sayur mengandung serat, vitamin, mineral, dan fitokimia sehingga berperan penting dalam kesehatan tubuh. Kubis merupakan salah satu sayuran yang sering dikonsumsi oleh masyarakat. Sayuran kubis sendiri dimanfaatkan sebagai lalapan yang dikonsumsi dalam kondisi mentah.Ditambah lagi morfologi sayuran kubis yang sangat dekat dengan tanah. Konsumsi sayuran mentah sebagai lalapan berisiko memberikan kontribusi penularan cacing melalui jalur oral dan bahkan akan mempengaruhi kesehatan masyarakat. Kebiasaan memakan sayuran mentah (lalapan) perlu hati-hati terutama jika dalam pencucian kurang baik sehingga memungkinkan masih adanya telur cacing pada sayuran kubis (Lobi, 2016).

Kubis merupakan salah satu sayuran yang menjadi unggulan petani dataran tinggi di Bali, selain tomat dan wortel (Yuliadhi dan Sudiarta, 2012). Tanaman kubis yang dibudidayakan di Bali tersebar di daerah Tabanan, Buleleng, Bangli dan Gianyar. Produksi kubis pada tahun 2010 mencapai 47.077 ton. Namun produksi tersebut menurun pada tahun 2011 mencapai 42.928 ton yang diproduksi oleh seluruh daerah pusat pengembangan sayuran di Bali. Sayuran kubis juga bermanfaat untuk berbagai kesehatan seperti sebagai antioksidan, anti inflamasi, dan antibakteri (Kumarawati et al., 2017).

Penelitian STH pada sayuran masih jarang dilakukan, hal ini karena 1) bidang kedokteran lebih banyak terfokus pada pemeriksaan feses manusia sebagai pasien, 2) ilmu di bidang non kedokteran seperti biologi, pangan, dan lingkungan 
WIDYA BIOLOI

tidak semuanya mempelajari helmintologi (ilmu cacing) (Adrianto, 2016). Berdasarkan penjelasan tersebut peneliti bermaksud melakukan penelitian tentang Kontaminasi Soil Transmitted Helminth Pada Helaian Daun dan Cara Pencucian Sayuran Kubis di Pasar Tradisional Kabupaten Tabanan.

\section{BAHAN DAN METODE}

\section{Waktu dan Tempat Penelitian}

Penelitian dilaksanakan dari bulan April - Mei 2018 bertempat di dua tempat yaitu pasar tradisional di Kabupaten Tabanan dan Laboratorium Parasitologi Fakultas Kedokteran Universitas Udayana Denpasar.

\section{Bahan dan Alat Penelitian}

Bahan yang digunakan dalam penelitian ini meliputi; (1). Aquadest, (2). $\mathrm{NaOH} 0,2 \%$, (3). Kubis, (4). Pewarnaan malachite green, (5) selofane tape, sedangkan peralatan yang digunakan adalah (1). Tabung reaksi, (2). baskom, (3). centrifuge, (4). kaca objek, (5) pinset, (6) yellow tip, (7) mikropipet (8) mikroskop binokuler, (9) rak tabung (10). timbangan, (11). Pisau dapur, (12) handscone (13). Pipet tetes, (14) beker glass, (15) batang pengaduk.

\section{Rancangan Penelitian}

E ISSN :

Rancangan penelitian yang digunakan dalam penelitian ini sebagai rancangan dasar adalah Rancangan Acak Lengkap. Sedangkan rancangan perlakuannya adalah rancangan faktorial.

\section{Populasi, Sampel dan Unit Penelitian}

Populasi penelitian ini adalah sayuran kubis yang dijual di pasar tradisional Kabupaten Tabanan. Kabupaten Tabanan terdiri atas 10 kecamatan diantaranya : Kecamatan Pupuan, Kecamatan Selemadeg Barat, Kecamatan Selemadeg, Kecamatan Selemadeg Timur, Kecamatan Kerambitan, Kecamatan Tabanan, Kecamatan Kediri, Kecamatan Marga, Kecamatan Penebel, Kecamatan Baturiti. Dimasing-masing kecamatan diambil 1 (satu) pasar tradisional.

Dari survey awal di 10 pasar tradisional yang ada di kabupaten Tabanan, diperoleh data jumlah pedagang yang menjual sayuran kubis sebanyak 102 pedagang sayur kubis yaitu, pasar pupuan terdapat 10 pedagang sayuran kubis, pasar Surabrata terdapat 4 pedagang sayuran kubis, pasar Bajera terdapat 6 pedagang sayur kubis, pasar Megati terdapat 2 pedagang sayur kubis, pasar Kerambitan terdapat 5 
WIDYA BIOLOI

E ISSN :

pedagang kubis, pasar Dauh pala terdapat 8 pedagang kubis, pasar Kediri terdapat 19 pedagang sayuran kubis, pasar Marga terdapat 7 pedagang sayur kubis, pasar penebel terdapat 8 pedagang sayur kubis, pasar Baturiti terdapat 33 pedagang sayur kubis.

Dari total jumlah pedagang sayuran kubis maka besar sampel yang diambil adalah $10 \%$ dari masing-masing pasar. Pemilihan pedagang dilakukan dengan Simple random sampling yaitu teknik pengambilan secara acak sederhana dimana populasi mempunyai kesempatan yang sama untuk diseleksi sebagai sampel (Sugiyono, 2013). Sehingga dipilih 14 pedagang sampel penelitian.
Bajera, Megati, Kerambitan, Dauh Pala, Marga dan Penebel diambil masingmasing 1 buah pedagang kubis, sedangkan di Pasar Kediri sebanyak 2 pedagang kubis dan di Pasar Baturiti diambil sebanyak 4 pedagang kubis. Masing-masing pedagang diambil 2 buah sayuran kubis, sehingga total kubis diperoleh adalah 28 buah sayur kubis.

\section{HASIL DAN PEMBAHASAN}

\section{HASIL}

Dari pemeriksaan sampel kubis ditemukan jenis larva filariformNecator americanus yang disajikan pada tabel 4.2 dan larva filariformAncylostoma duodenale disajikan pada tabel 2.1.

Di pasar tradisonal Pupuan, Surabrata,

Tabel 2.1 Hasil Pemeriksaan Soil Transmitted Helminth (Larva filariformNecator americanus) pada Sayuran Kubis di Kabupaten Tabanan

\begin{tabular}{lccccc}
\hline \multirow{2}{*}{$\begin{array}{l}\text { Kombinasi } \\
\text { perlakuan }\end{array}$} & \multicolumn{3}{c}{ Ulangan } & Jumlah & Rata-rata \\
\cline { 2 - 4 } $\mathrm{D}_{1} \mathrm{P}_{0}$ & 4 & 6 & 5 & 15 & 5 \\
\hline $\mathrm{D}_{1} \mathrm{P}_{1}$ & 1 & 0 & 1 & 2 & 0,67 \\
\hline $\mathrm{D}_{1} \mathrm{P}_{2}$ & 0 & 0 & 0 & 0 & 0 \\
\hline $\mathrm{D}_{2} \mathrm{P}_{0}$ & 0 & 0 & 0 & 0 & 0 \\
\hline $\mathrm{D}_{2} \mathrm{P}_{1}$ & 0 & 0 & 0 & 0 & 0 \\
\hline $\mathrm{D}_{2} \mathrm{P}_{2}$ & 0 & 0 & 0 & 0 & 0 \\
\hline $\mathrm{D}_{3} \mathrm{P}_{0}$ & 0 & 0 & 0 & 0 & 0 \\
\hline $\mathrm{D}_{3} \mathrm{P}_{1}$ & 0 & 0 & 0 & 0 & 0 \\
\hline $\mathrm{D}_{3} \mathrm{P}_{2}$ & 0 & 0 & 0 & 0 & 0
\end{tabular}

Keterangan : $\mathrm{D}_{1} \mathrm{P}_{0}$ (Helaian luar tanpa pencucian), $\mathrm{D}_{1} \mathrm{P}_{1}$ (helaian luar dengan dicuci air tergenang), $\mathrm{D}_{1} \mathrm{P}_{2}$ (helaian luar dicuci air mengalir), $\mathrm{D}_{2} \mathrm{P}_{0}$ (helaian tengah tanpa dicuci), $\mathrm{D}_{2} \mathrm{P}_{1}$ (helaian tengah dengan dicuci air tergenang), $\mathrm{D}_{2} \mathrm{P}_{2}$ (helaian tengah dicuci air mengalir), $\mathrm{D}_{3} \mathrm{P}_{0}$ (helaian dalam tanpa dicuci), $\mathrm{D}_{3} \mathrm{P}_{1}$ (helaian dalam dicuci air tergenang), $\mathrm{D}_{3} \mathrm{P}_{2}$ (helaian dalam dicuci air mengalir) 
Pada tabel 2.1 di atas dijelaskan bahwa larva filariform Necator americanus ditemukanpada helaian daun posisi terluar tanpa dilakukan pencucian dan dicuci air tergenang. Dari tiga ulangan pada helaian terluar tanpa pencucian diperoleh rata-rata larva filariform Necator americanus 5. Sedangkan pada helaian daun posisi terluar dicuci air tergenang diperoleh 0,67 dari tiga ulangan. Pada helaian terluar dengan dicuci air mengalir tidak ditemukan adanya STH baik larva maupun telur, begitu pula pada helaian tengah dan dalam baik tanpa pencucian, dicuci air tergenang dan dicuci air mengalir.

Tabel 2.2 Hasil PemeriksaanSoil Transmitted Helminth(Larva filariform Ancylostoma duodenale) pada Sayuran Kubis di Kabupaten Tabanan

\begin{tabular}{lccccc}
\hline Kombinasi & \multicolumn{3}{c}{ Ulangan } & \multirow{2}{*}{ Jumlah } & Rata-rata \\
\cline { 2 - 5 } perlakuan & I & II & III & & 0,67 \\
\hline $\mathrm{D}_{1} \mathrm{P}_{0}$ & 1 & 0 & 1 & 2 & 0 \\
\hline $\mathrm{D}_{1} \mathrm{P}_{1}$ & 0 & 0 & 0 & 0 & 0 \\
\hline $\mathrm{D}_{1} \mathrm{P}_{2}$ & 0 & 0 & 0 & 0 & 0 \\
\hline $\mathrm{D}_{2} \mathrm{P}_{0}$ & 0 & 0 & 0 & 0 & 0 \\
\hline $\mathrm{D}_{2} \mathrm{P}_{1}$ & 0 & 0 & 0 & 0 & 0 \\
\hline $\mathrm{D}_{2} \mathrm{P}_{2}$ & 0 & 0 & 0 & 0 & 0 \\
\hline $\mathrm{D}_{3} \mathrm{P}_{0}$ & 0 & 0 & 0 & 0 & 0 \\
\hline $\mathrm{D}_{3} \mathrm{P}_{1}$ & 0 & 0 & 0 & 0 & 0 \\
\hline $\mathrm{D}_{3} \mathrm{P}_{2}$ & 0 & 0 & 0 & 0 & \\
\hline
\end{tabular}

Keterangan : $\mathrm{D}_{1} \mathrm{P}_{0}$ (Helaian luar tanpa pencucian), $\mathrm{D}_{1} \mathrm{P}_{1}$ (helaian luar dengan dicuci air tergenang), $\mathrm{D}_{1} \mathrm{P}_{2}$ (helaian luar dicuci air mengalir), $\mathrm{D}_{2} \mathrm{P}_{0}$ (helaian tengah tanpa dicuci), $\mathrm{D}_{2} \mathrm{P}_{1}$ (helaian tengah dengan dicuci air tergenang), $\mathrm{D}_{2} \mathrm{P}_{2}$ (helaian tengah dicuci air mengalir), $\mathrm{D}_{3} \mathrm{P}_{0}$ (helaian dalam tanpa dicuci), $\mathrm{D}_{3} \mathrm{P}_{1}$ (helaian dalam dicuci air tergenang), $\mathrm{D}_{3} \mathrm{P}_{2}$ (helaian dalam dicuci air mengalir)

Pada Tabel 2.2 dijelaskan bahwa larva filariform Ancylostoma duodenale hanya ditemukan pada helaian daun posisi terluartanpa dilakukan pencucian. Dari rata-rata tiga ulangan diperoleh larva filariformAncylostoma duodenale sebanyak 0,67. Pada helaian daun posisi luar dengan dicuci air tergenang dan air mengalir tidak ditemukan larva filariformAncylostoma duodenale begitu pula pada posisi helaian tengah dan helaian dalam baik tanpa pencucian, dicuci air tergenang dan dicuci air mengalir. 


\section{WIDYA BIOLOI E ISSN :}

\section{PEMBAHASAN}

Pada posisi helaian luar sayur kubis ditemukan larva cacing tambang, sedangkan pada posisi helaian tengah dan paling dalam tidak ditemukan adanya larva cacing tambang. Hal ini terjadi karena morfologi sayuran kubis yang berlekuk-lekuk dan pada helaian bagian tengah maupun bagian dalam tidak mengalami kontak langsung dengan tanah, sehingga tidak ditemukan adanya telur maupun larva cacing tambang. Larva yang baru menetas aktif memakan sisa-sisa pembusukan organik, dan cepat bertambah besar, kemudian menjadi larva filariform yang infeksius (Irianto, 2013). Selain itu pula telur maupun larva cacing tambang tidak masuk hingga helaian tengah dan dalam, hal ini diduga karena tidak ada nutrisi yang sesuai untuk kebutuhan perkembangan hidup cacing tambang. Berbeda halnya pada manusia, larva cacing tambang dapat menembus kulit dan masuk ke pembuluh darah hingga ke saluran pencernaan. Hal ini dikarenakan larva cacing tambang berusaha memperoleh nutrisi untuk perkembangannya, baik berupa darah maupun mengambil sari-sari makanan pada manusia. (Gandahusaha et al.,
1998). Kemungkinan lain adalah karena dihasilkan metabolit sekunder yaitu glikosikolat. Glukosinolat menjadi toksik setelah mengalami hidrolisis. Proses hidrolisis dari glukosinolat membutuhkan enzim mirosinase dan air. Salah satu hasil dari hidrolisis glukosinolat adalah isotiosianat yang bersifat volatil dan toksik. Sifat tersebut menyebabkan kubis dapat digunakan sebagai biofumigan untuk mengendalikan nematoda parasit tanaman (Yulianti dan Supriadi 2008). Pada bagian yang lebih tua konsentrasi glukosinolat sangat rendah yaitu $<0,3$ $\mu \mathrm{mol} / \mathrm{ml}$ jaringan. Daun yang sedang tumbuh konsentrasi glukosinolat mencapai4-5 $\mu \mathrm{mol} / \mathrm{ml}$ air jaringan (Porter et al., 1991).

Pada helaian luar sayuran kubis tanpa pencucian ditemukan lebih banyak larva dibandingkan dengan pencucian pada air tergenang. Hal ini terjadi karena larva cacing terlepas saat dilakukan pencucian dengan air di dalam wadah, dan pada pencucian dengan air mengalir menyebabkan kotoran yang ada akan terbawa air yang mengalir tersebut, termasuk larva cacing yang masih menempel pada daun kubis. Pada perlakuan pencucian daun kubis pada air 


\section{WIDYA BIOLOI}

E ISSN :

tergenang hanya ditemukan sedikit larva dan pada ulangan kedua tidak ditemukan adanya larva cacing tambang, hal ini terjadi karena larva kemungkinan terlepas saat dilakukan pencucian, sehingga hasil pemeriksaan negatif.

Penggunaan air mengalir lebih dianjurkan daripada menggunakan air yang diam (menggenang), seperti air dalam wadah/bak air yang digunakan untuk mencuci sayuran secara berulang. Hal ini dapat berpengaruh terhadap resiko pencemaran oleh berbagai jenis bahan pencemar baik organik maupun anorganik (pestisida). Selama periode penanaman sayur juga terdapat pengaruh lingkungan yang memungkinkan terjadinya ketidakamanan pangan dan terdapat sisa-sisa kotoran. Sehingga pencucian mutlak diperlukan sebelum sayur dikonsumsi (Astawan, 2006).

Penelitian terkait yang dilakukan oleh Okdiyanzah dan Widiastuti (2012), dari 20 sampel sampel kubis dari pasar swalayan dan 20 sampel dari pasar tradisional semuanya terkontaminasi oleh telur STH, dengan jenis STH yang ditemukan pada sayuran kubis di pasar tradisional antara lain Ascaris lumbricoides $(59,1 \%)$, Tricuris triciura $(19,8 \%)$, cacing tambang (58,5\%).
Sementara yang ditemukan pada sayuran kubis di pasar swalayan antara lain :Ascaris lumbricoides (57,8\%), Tricuris triciura $(13,7 \%$, cacing tambang $(3,1 \%)$

Pada penelitian ini ditemukan cacing tambang berupa larva filariform cacing tambang dan tidak ditemukan jenis STH yang lain seperti Ascaris lumbricoides (cacing gelang), Trichuris trichiura (cacing cambuk), Strongyloides stercolaris (cacing benang). Hal ini terjadi karena cacing tambang dapat hidup baik pada tanah berpasir yang gembur dan bercampur humus dengan kelembaban yang tinggi. Di Indonesia prevalensi kecacingan akibat spesies ini masih cukup tinggi, terutama di daerah pedesaan, khususnya perkebunan sekitar 40\%. Sedangkan Ascaris lumbricoides dan Trichuris triciura tumbuh baik pada tanah liat yang lembab dan teduh. Ascaris lumbricoides berkembang dengan baik pada udara yang hangat dengan temperatur $25^{\circ} \mathrm{C}-30^{\circ} \mathrm{C}$, sedangkan Tricuris triciura suhu optimum untuk tumbuh adalah pada suhu $30^{\circ} \mathrm{C}$. Cacing Strongloides stecoralis memiliki stadium bebas, untuk kelangsungan hidupnya 
WIDYA BIOLOI

E ISSN :

memerlukan suhu rata-rata kira-kira $15^{0} \mathrm{C}$ (Irianto, 2013).

Sayuran yang ditata di tempat yang terbuka dan tidak bersih dapat tercemar oleh telur cacing. Telur cacing yang ada di tanah/ debu akan terbawa angin dan sampai pada makanan. Selain itu transmisi telur cacing juga dapat melalui lalat yang sebelumnya hinggap di tanah/kotoran, sehingga kaki-kakinya membawa telur cacing dan mencemari makanan-makanan yang tidak tertutup (Verdira, 2014).

Stadium cacing tambang yang ditemukan berupa larva filariform. Hal ini dikarenakan perkembangan telur cacing tambang menjadi larva memerlukan waktu 1-2 hari, melepaskan larva rhabditiform, setelah 3 hari larva rhabditiform mengalami perubahan menjadi larva infektif yaitu larva filariform yang mampu hidup selama 7-8 minggu di tanah (Gandahusada et al., 1998). Sehingga sangat memungkinkan hanya ditemukannya stadium larvafilariformcacing tambang pada sayuran kubis yang diperiksa. Menurut Musyawaroh (2012), tempat penyimpanan sayuran tidak bersih dan lembab, memungkinkan untuk telur STH untuk berkembang menjadi bentuk infektif.

Spesies yang ditemukan adalah larva filariformcacing tambang yaitu Necator americanus dan Ancylostoma duodenale. Secara morfologi yang membedakan dari larva filariformNecator americanus dan Ancylostoma duodenale adalah bentuk tubuh, ujung anterior dan anus. Necator americanusmemiliki bentuk tebal di bagian tengah tubuh,ujung anterior sempit dan bundardan anus tiba-tiba meruncing, ujungnya sedikit tajam (Suzuki, 1975).

Larva filariform Ancylostoma duodenale berbentuk ramping, ujung anterior datar dan agak lebar.Bentuk ekor Ancylostoma duodenalesecara bertahap meruncing dari anus (Suzuki, 1975).

Larva Necator americanus lebih banyak ditemukan karena lingkungan yang cukup kondusif untuk perkembangan hidupnya. Larva cacing tambang sangat baik pertumbuhannya pada tanah yang gembur dan bercampur humus serta teduh. Larva Ancylostoma duodenaleakan tumbuh optimum pada suhu berkisar $23-25^{\circ} \mathrm{C}$, sedangkan untuk 
WIDYA BIOLOI

E ISSN :

Necator americanus berkisar antara 28$32^{\circ} \mathrm{C}$ (Supali et al., 2008).

Kontaminasi STH yang ditularkan melalui tanah pada sayuran kubis dapat dikarenakan oleh berbagai faktor antara lain adalah faktor alam. Faktor alam meliputi, tanah, iklim, kelembaban dan suhu. Iklim tropik merupakan salah satu hal yang berpengaruh terhadap pertumbuhan dan perkembangan telur STH, faktor alam lainnya adalah keadaan tanah yang dapat menjadi media perkembangan telur dan kehidupan serta perkembangan larva. Tanah yang subur dan kaya bahan organik yang ditunjang dengan kelembaban dan iklim yang sesuai bagi pertumbuhan sayuran khususnya sayuran kubis juga merupakan faktor adanya kontaminasi telur nematoda usus. Tanah yang terkontaminasi lebih memungkinkan sayuran kubis terkontaminasi dari segi morfologi dan perlekatan ke tanah, sehingga STH lebih mudah melekat pada sayuran (Nugroho et al., 2010).

Manusia juga memberikan kontribusi yang cukup berarti terhadap penyebaran infeksi STH. Sanitasi lingkungan yang buruk, sosial ekonomi yang rendah, tingkat pengetahuan yang masih kurang dan kebiasaan defekasi di sembarang tempat terutama di lahan pertanian/perkebunan serta kebiasaan kurang bersihnya dalam pengelolaan sayuran di tingkat produsen dan pengolahannya di tingkat konsumen memberikan pengaruh yang cukup signifikanterhadap peningkatan kasus penyakit tersebut (Nugroho et al., 2010).

\section{SIMPULAN}

Terjadi kontaminasi sayuran kubis di Pasar Tradisional oleh Soil Transmitted Helminth. Jenis Soil Transmitted Helminth yang mengontaminasi sayuran kubis di pasar tradisonal Kabupaten Tabanan adalah larva filariform Necator americanus dan Ancylostoma duodenale.

Helaian daun kubis terluar tanpa pencucian terkontamnasi larvafilariform Necator americanus dan Ancylostoma duodenale, sedangkan helaian kubis terluar dengan pencucian air tergenang hanya terkontaminasi larva Necator americanus. Helaian daun kubis bagian tengah dan dalam tidak terkontaminasi STH baik tanpa pencucian, pencucian air tergenang dan pencucian air mengalir. 


\section{SARAN}

Sayur yang dikonsumsi secara mentah khususnya sayur kubis sebaiknya dilakukan pencucian dengan air mengalir dan helaian terluar dibuang terlebih dahulu. Untuk penelitian selanjutnya dilakukan pemeriksaan parasit pada jenis sayuran berbeda yang biasa dikonsumsi secara mentah seperti wortel dan selada.

\section{DAFTAR PUSTAKA}

Adrianto, Herbert. 2017. Kontaminasi Telur Cacing pada Sayur dan Upaya Pencegahannya Helminth Eggs Contamination in Vegetables and Prevention Efforts. Parasitologi, Fakultas Kedokteran, Universitas Ciputra (serial

https://media.neliti.com/media/pu blications/222703-kontaminasitelur-cacing-pada-sayur-dan.pdf. Akses 27 Januari 2018.

Anonim. 2017. Kubis. (serial online),Avaible at : https://daunbuah.com/gambarkol-dan-kubis/. Akses tanggal 1 April 2018.

Astuti, R., Siti, A. 2008. Identifikasi Telur Cacing Usus Pada Lalapan Daun Kubis Yang Dijual Pedagang Kaki Lima di Kawasan Simpang LimaKota Semarang.Proseding Seminar Nasional: Continuing Medical and Health Education (CMHE), Vol. 1, No. 1, Hlm. 297 -307, (serial online), Avaible from : jurnal.unimus.ac.id/index.php/ps n12012010/article/view/133/114. Akses tanggal 26 Januari 2018.

Bhandari RB, Jung SJ, Jun GL. 2015. Comparison of glucosinolate profiles in different tissues of nine Brassica crops. Journal of Molucules. 20: 15827- 15841

Centers for Disease Cont and Prevention (CDC), 2013. Hookworm : Biology, Atlanta: Center for Disease Control and Prevention. (serial online), Avaible from: http://www.cdc.gov/parasites/hoo kworm/biology.html.Akses tanggal 26 Januari 2018.

Centers for Disease Control and Prevention (CDC), 2013. Trichuriasis : Biology, Atlanta: Center for Disease Control and Prevention (serial online), Avaible from : http://www.cdc.gov/parasites/whi pworm/biology.html. Akses 26 Januari 2018.

Centers for Disease Control and Prevention (CDC.) 2018. Ascariasis : biology, atlanta: center for disease control and prevention. (serial online),Avaible from : http://www.cdc.gov/parasites/asc ariasis/biology.html Akses 26 Januari 2018.

Cheesbrough, M. 1991. Techniquws used t Identify Parasites, Medical Laboratory Manual for Tropical Countries. Edisi 2. ButterworthHememanm Ltd, Oxford, UK.

Chen X, Zhujun Z, Joska G, Nadine Z. 2008. Glucosinolates in chinese 
WIDYA BIOLOI

E ISSN :

Brassica campestris vegetables: chinese cabbage, purple cai-tai, choysum, pakchoi, and turnip. Horticultural Science. 43(2): 571-574

Damayanti. 2012. Pengobatan dan penilaian Status Gizi anak Sd N 1 Luwus, Baturiti Yang Menderita Kecacingan (Soil Transmitted Helminths). Jurnal Udayana Mengabdi (serial online), Avaible from:

http://ojs.unud.ac.id/index.php/ju m/article/view. Akses 3 Februari 2018.

Das, S., Tyagi, A.K., Kaur, H. 2000. Cancer modulation by glucosinolates: A review. Current Science 79 (12): 1665-1671.

Endrawati, Heni. 2011. Pemeriksaan Tinja Metode Kato Katz (serial online) Avaible from: http://analisisduniakesehatan.blo gspot.com/2001/11/06pemeriksaan tinja-metode-kato katz.html. Akses 2 April 2018.

Gandahusada, Srisasi., Herry D. Illahue, Wita Pribadi. 1998. Parasitologi Kedokteran, Edisi III, FKUI. Jakarta.

Irianto, Koes. 2013.Parasitologi Medis. Alfabeta. Bandung.

Ismid Is, Winita R, Sutanto I, Zulhasril, Sjarifuddin Pk. 2000.Penuntun Praktikum Parasitology Kedokteran. Jakarta: Fakultas Kedokteran Universitas Indonesia. Jurnal Kesmas Uad. 2010;6(2):162-232.
Kapti I N, Luh Ariwati, Made Sudarmaja, 2004. Pengobatan Penyakit Cacing Usus pada Anak-Anak SD Di Bali Periode 2003-2007. Jurnal Pengabdian Masyarakat Udayana Mengabdi, Vol 3 No 2 tahun 2004, Lembaga Pengabdian Masyarakat Unud (serial online) Avaible from: https://ojs.unud.ac.id/index.php/j um/article/view/6446. Akses 2 $\underline{\text { Februari } 2018}$

Kumarawati N, Supartha I, Yuliadhi K. Struktur Komunitas Dan Serangan Hama-Hama Penting Tanaman Kubis (Brassica Oleracea L.) Agroteknologi Tropika (serial online) Avaible from:

http://ojs.ac.id/index.php/jat. Akses 27 Januari 2018.

Lobi Leonardo Taruk, Et Al. 2016. Kontaminasi Telur Cacing Soil Transmitted Helminth Pada Sayuran Kemangi Pedagang Kaki Lima Di Kota Palu Sulawesi Tengah. Sulawesi Tengah: Media Litbangkes, Vol. 26 No. 2, Juni 2016, 65 - 70 (serial online) Avaible from :ejournal.litbang.depkes.go.id/in dex.php/MPK/article/view. Akses tanggal 30 Januari 2018.

Mastuti, Retno. 2016. Metabolit Sekunder Dan Pertahanan Tumbuhan. Jurusan Biologi, FMIPA Universitas Brawijaya

Margono SS. 2008. Nematoda Usus. Buku Ajar Parasitologi Kedokteran Edisi 4. FKUI. Jakarta. 
WIDYA BIOLOI

Mutiara H. 2011. Identifikasi Kontaminasi Telur Soil Transmitted Helminths Pada makanan Berbahan Sayuran Mentah Yang Diajukan Kantin Sekitar Kampus Universitas Lampung Bandar Lampung (serial online),Avaible from download.portalgaruda.org/artic le.php?...Identifikasi\%20Kontami $n$. Akses 28 Januari 2018.

Muyassaroh S, Rahayu A, Wulandari M, 2012. Pengaruh Frekuensi Pencucian Pada Daun Kubis (Brassica oleracea var Capitata) Terhadap Jumlah Cacing Usus (Nematoda Intestinal). Universitas Muhammadiyah Semarang. Semarang. (serial online),Avaible from http://jurnal.unimus.ac.id. Akses tanggal 11 Juni 2018.

Nitalessy, R. Woodford B.S. Joseph, Joice R.S.T.L. Rimper. 2015. Keberadaan Cemaran Telur Cacing Usus Pada Sayuran Kemangi (Ocimum Basilicum) Dan Kol (Brassica Oleracea) Sebagai Menu Pada Ayam Lalapan Di Warung Makan Jalan Piere Tendean Kota Manado Tahun 2015.(serial online),Avaible from : medkesfkm.unsrat.ac.id/.../kebera daan-cemaran-telur-cacing-usus. Akses tanggal 28 Januari 2018.

Nugroho, C., Sitti, ND., Surahma, AM. 2010. Identifikasi Kontaminasi Telur Nematoda Usus Pada Sayuran Kubis (Brassica oleracea) Warung Makan Lesehan Wonosari Gunung Kidul Yogyakarta Tahun 2010. Jurnal Kesehatan

Masyarakat
E ISSN :

Universitas Ahmad Dahlan (serial Online), Avaible from :Avaible from : medkesfkm.unsrat.ac.id/.../kebera daan-cemaran-telur-cacing-usus. Akses 30 Juni 2018.

Okdiyanzah Suayday Dan Widiastuti, 2014. Kontaminasi Parasit Usus Pada Sayuran Kubis Pasar Tradisional Dan Swalayan Jakarta Dengan Perendaman Larutan Garam-Cuka Tahun 2014. Jakarta: Program Pendidikan Dokter Fakultas Kedokteran Unversitas Indonesia. (serial online),Avaible from:

www.digilib.ui.ac.id/naskahringk as/2017-01/S-Suaydiy. Akses tanggal 28 Januari 2018.

Oktavia. Galuh. 2007. Redesain Pasar Jongke Surakarta. Skripsi S1.Fak. Teknik .Jur.Arsitektur, Universitas Atma Jaya. (serial online). Avaible from: $e$ journal.uajy.ac.id/835/2/1TA127 04.pdf. Akses tanggal 28 Maret 2018.

Peraturan Presiden RI nomor 112. 2007. Penataan dan Pembinaan Pasar Tradisional, Pusat pembelanjaan dan Toko Modern (serial online), avaible from: www.hukumonline.com. Akses 28 Maret 2018.

Porter.A.J.R, A.M. Mortan, G.Kiddle, K.J.Doughty, R.M.Wallsgrove. 1991. Variation in the Glucosinolate Content of Oilseeds Rape (Brassica napus L) Leaves (serial online) Avaible from: 


\section{WIDYA BIOLOI E ISSN :}

http://dol.org/10.1111/j.17447348.1991.tb05647.x. Diakses tanggal 5 September 2018.

Pracaya. 1981. Kol Alias Kubis. PT Penebar Swadaya. Jakarta Pusat.

Redovniković IR, Tatjana G, Karmela D, Jasna FV. 2008. Glucosinolates and their potential role in plant. Periodicum Biologorum. 110(4):297-309.

Rubatzky, Vincent E dan Mas Yamaguchi. 1998. Sayuran Dunia Prinsip, Produksi dan Gizi Jilid kedua. ITB. Bandung.

Rukmana. 2001. Bertanam Kubis. Kanisius. Yogyakarta.

Sugiyono. 2013. Metode Penelitian Kuantitatif Kualitatif Dan R \& D.Alfabeta. Bandung.

Supali, T., Margono, S. S., dan Abidin, S. A. N., 2008. Buku Ajar Parasitologi Kedokteran. Edisi ke 4. Balai Penerbit Fakultas Kedokteran Universitas Indonesia. Jakarta.

Suzuki, N. 1975. Colour Atlas Of Human Helminth Eggs. Seamic. Tokyo Japan.

Verdira. 2014. Distribusi frekuensi Soil Transmitted Helminth pada sayuran selada (Lactuca sativa) yang dijual di pasar tradisonal dan pasar modern di Kota Padang. (Serial online) Avaible from: http//jurnal.fk.unand.ac.id. Akses 10 Juni 2018.
Wardhana, Kurniawan, B., Mustofa, S. 2014. Identifikasi Telur Soil Transmitted Helminths Pada Lalapan Kubis (Brassica Oleraceae) Di Warung -Warung Makan Universitas Lampung. Medical Journal Of Lampung University Vol. 3, No. 3, Hlm. 86-95. (Serial online) Avaible from:

Juke.Kedokteran.Unila.Ac.Id. Akses 27 Maret 2018.

World Health Organization. 2013. Soil Transmitted Helminthases

Eliminating Soil Transmitted Helminthases as a public Health Problem in Children. (Serial online). Avaible from: http://whqblibloc.who.int/publicr elation/2013.pdf. tanggal 30 Januari 2018.

Yousef MMA. 2015. Biofumigation as a promising tool for managing plant parasitic nematodes: A review. Scientia Agriculturae. 10(3): 115-118.

Yuliadhi dan Sudiarta. 2012. Strukur Komunitas Hama Pemakan Daun Kubis dan Investigasi Musuh Alaminya. Agrotop 2(2): 191196 (2012) ISSN: 2088-155 X Fakultas Pertanian Udayana DPS. Bali (serial online) Avaible from: docplayer.info/46458899E-jurnal-agroekoteknologi. Akses tanggal 21 Februari 2018.

Yulianti T, Supriadi. 2008. Biofumigan untuk pengendalian patogen tular tanah penyebab penyakit tanaman yang ramah lingkungan. Perspektif. 7(1):20-34. 